Brazilian Journal of Microbiology (2009) 40: 470-479

ISSN 1517-8382

\title{
PERFORMANCE OF TRANSPORT AND SELECTIVE MEDIA FOR SWINE BORDETELLA BRONCHISEPTICA RECOVERY AND IT COMPARISON TO POLYMERASE CHAIN REACTION DETECTION
}

\author{
Coutinho, Tania Alen ${ }^{1}$; Bernardi, Mari Lourdes ${ }^{2}$; Cardoso, Marisa Ribeiro de Itapema ${ }^{1}$; Borowski, Sandra Maria ${ }^{3}$; \\ Moreno, Andrea Micke ${ }^{4}$; Barcellos, David Emilio Santos Neves de ${ }^{1^{*}}$ \\ ${ }^{1}$ Faculdade de Veterinária, Universidade Federal do Rio Grande do Sul, Porto Alegre, RS, Brasil; ${ }^{2}$ Faculdade de Agronomia, \\ Universidade Federal do Rio Grande do Sul, Porto Alegre, RS, Brasil; ${ }^{3}$ Instituto de Pesquisas Veterinárias "Desidério \\ Finamor”, Eldorado do Sul, RS, Brasil; ${ }^{4}$ Faculdade de Medicina Veterinária e Zootecnia, Universidade de São Paulo, São \\ Paulo, SP, Brasil.
}

Submitted: October 20, 2008; Returned to authors for corrections: November 25, 2008; Approved: May 04, 2009.

\begin{abstract}
Three comparative assays were performed seeking to improve the sensitivity of the diagnosis of Bordetella bronchiseptica infection analyzing swine nasal swabs. An initial assay compared the recovery of B. bronchiseptica from swabs simultaneously inoculated with B. bronchiseptica and some interfering bacteria, immersed into three transport formulations (Amies with charcoal, trypticase soy broth and phosphate buffer according to Soerensen supplemented with 5\% of bovine fetal serum) and submitted to different temperatures $\left(10^{\circ} \mathrm{C}\right.$ and $\left.27^{\circ} \mathrm{C}\right)$ and periods of incubation $(24,72$ and 120 hours). A subsequent assay compared three selective media (MacConkey agar, modified selective medium G20G and a ceftiofur medium) for their recovery capabilities from clinical specimens. One last assay compared the polymerase chain reaction to the three selective media. In the first assay, the recovery of $B$. bronchiseptica from transport systems was better at $27^{\circ} \mathrm{C}$ and the three formulations had good performances at this temperature, but the collection of qualitative and quantitative analysis indicated the advantage of Amies medium for nasal swabs transportation. The second assay indicated that MacConkey agar and modified G20G had similar results and were superior to the ceftiofur medium. In the final assay, polymerase chain reaction presented superior capability of $B$. bronchiseptica detection to culture procedures.
\end{abstract}

Key words: Bordetella bronchiseptica, swine, transport media, selective media, PCR

*Corresponding Author. Mailing address: Faculdade de Veterinária da Universidade Federal do Rio Grande do Sul (UFRGS), Av. Bento Gonçalves 9090 , CEP 91 540-000, Porto Alegre, RS, Brasil.; Fone/Fax: (51) 3316-6864.; Email: davidbarcellos@terra.com.br 


\section{INTRODUCTION}

One of the main respiratory disease entities in swine production is the rhinitis. The cause of swine rhinitis is often infectious (Bordetella bronchiseptica, Mycoplasma hyorhinis, cytomegalovirus and Aujeszky's disease virus), but ammonia and dust as well as foreign bodies can also induced mild mucosal inflammation of short duration (4). However, when toxigenic strains of Pasteurella multocida are present in damaged nasal mucosa, it might adhere, proliferate and subsequently provoke progressive atrophic rhinitis with permanent alteration of the nasal structure and function (4).

B. bronchiseptica is the mainly primary etiologic agent of atrophic rhinitis in swine and bronchopneumonia in young piglets and represents a major impact to swine health worldwide (26). Although clinical signs of atrophic rhinitis can be suggestive of $B$. bronchiseptica infection (4), a definitive diagnosis can be achieved by bacteriologic examination of nasal secretions (16). Swine nasal specimens are routinely shipped to laboratories under a variety of conditions: room temperature or under refrigeration, swabs immersed or not in transport medium with a transport time ranging from one to three days. Many other variables could interfere with the correct diagnosis, such as the primary isolation media employed to isolate the pathogen (13), since B. bronchiseptica grows more slowly than other bacteria present in the nasal cavity and the overgrowth with commensal flora during isolation procedures often occur (25).

Although bacterial culture represents a definitive diagnosis, it has some limitations. The culture processing of B. bronchiseptica use to consume two days and definitive tests should be lead only after subcultures (32). Even though bacteriological culture has a high diagnostic specificity, it diagnostic sensibility is low, since only a fraction of the total bacterial species is able to grow in artificial media $(7,17)$. Polymerase chain reaction (PCR) is a molecular technique of nucleic acids detection sensible and specific enough to permit an accurated diagnosis of many pathogens. This technique is not limited by the capability of microorganisms of growing in cultures, besides the amplicon characterization might provide epidemiological and phylogenetic informations.

Various PCR protocols have been developed that target different regions of the Bordetella spp. genome: insertion sequences IS481 and IS $1001(8,9,28,30)$, the pertussis toxin promoter region $(9,28)$ and the adenylate cyclase gene $(5)$. However, greater part of Bordetella PCR protocol is related $B$. pertussi species. In 1999 a specific PCR for $B$. bronchiseptica detection was described, which target region of amplification encoded the structural gene of flagelin (fla) (14). This sequence was chosen as target since $B$. bronchiseptica is the only one, between the three main Bordetella species (B. pertussis, B. parapertussis and $B$. bronchiseptica) to express the flagelin gene (32)

Currently, there are few data to support recommendations to increase the probability to detect $B$ bronchiseptica from swine nasal swabs. The purpose of this study was to establish the best conditions for the recovery of B. bronchiseptica from swine nasal swabs using the most efficient transport and primary isolation media. We also compared the isolation media and PCR technique for their abilities to detect B. bronchiseptica.

\section{MATERIALS AND METHODS}

\section{Determination of a transport medium}

The evaluated formulations to maintain the viability of $B$. bronchiseptica for 120 hours were Amies transport medium with charcoal (DIFCO 0832-17) (23), trypticase soy broth 
(TSB) (BD \& Co. - 211825) (15) and phosphate buffered according to Soerensen added $5 \%(\mathrm{v} / \mathrm{v})$ of bovine fetal serum $(\mathrm{PBS}+\mathrm{S})(29)$. The effect of storage temperature on the viability of $B$. bronchiseptica was also investigated. An isolate of $B$. bronchiseptica, obtained from Central Veterinary Laboratory, Weybridge, UK, was used in the experiments. Bacteria used for mixed cultures consisted of Pasteurella multocida, Streptococcus suis, Staphylococcus aureus, Escherichia coli and Pseudomonas aeruginosa obtained from the collection maintained at the "Instituto de Pesquisas Veterinárias Desidério Finamor”, Eldorado do Sul, Brazil. These bacteria were chosen because some of these genera represent the major microorganisms of the swine nasal flora (12) or because they are frequently isolated from swine nasal cavity as contaminants. Each swab was inoculated with $200 \mu \mathrm{L}$ of $B$. bronchiseptica $\left(10^{3} \mathrm{CFU} / \mathrm{mL}\right)$ and $4 \mu \mathrm{L}$ of mixed culture $\left(10^{2} \mathrm{CFU} / \mathrm{mL}\right)$, both diluted in PBS ( $\mathrm{pH}$ 7.3). Following this, swabs were immersed in tubes containing $2 \mathrm{~mL}$ of testing formulations and incubated at different temperatures $\left(10^{\circ} \mathrm{C}\right.$ or $\left.27^{\circ} \mathrm{C}\right)$ and periods $(24,72$ and 120 hours). A total of 180 swabs were used in the experiment, since ten repetitions of the assay were processed. Bacterial titer was determined by Miles \& Misra method (21) by inoculating serial 10-fold dilutions of swab cultures in PBS (pH 7.3) onto MacConkey agar (Oxoid CM7), incubating at $37^{\circ} \mathrm{C}$ for 48 hours and results were expressed as colony forming units (CFU)/mL.

\section{Determination of a primary isolation medium}

\subsection{Tested media}

A new selective medium for of $B$. bronchiseptica was developed to compare with two other specific isolation media. The selectivity in this new selective medium was guaranteed by the use of the antibiotic ceftiofur, due to the specific resistance of Bordetella to this drug (16) and the sensitivity of most of the bacteria present in swine nasal cavity (24). The minimal inhibitory concentration against ceftiofur reported previously for several swine bacteria (27) was the base to test five ceftiofur concentrations $(0.03 \mu \mathrm{g} / \mathrm{mL}$, $0.25 \mu \mathrm{g} / \mathrm{mL}, 0.5 \mu \mathrm{g} / \mathrm{mL}, 1.0 \mu \mathrm{g} / \mathrm{mL}$ and $1.5 \mu \mathrm{g} / \mathrm{mL}$ ) to apply in the new selective medium. This determination of ceftiofur concentration was assessed by an in vitro productivity and selectivity test previously described (18). At least ceftiofur medium was determined to contained per $\mathrm{mL}$ the following components: TSB (BD \& Co. - 211825) 30mg, glucose $7.5 \mathrm{mg}$, agar $20 \mathrm{mg}$, bromothymol blue $80 \mu \mathrm{g}$ and ceftiofur $1 \mu \mathrm{g}$.

The other isolation media tested were MacConkey agar and a modified G20G. The G20G was modified in relation to the original medium (29) in the following way: furazolidone was used instead of furaltadone and agar concentration was raised from $1.5 \%$ to $2.0 \%$.

\subsection{Animals}

A total of 50 piglets with age between 50-60 days from four different nurseries presenting sneezing were sampled. The four swine farms had an effective management practices and the sows were vaccinated against atrophic rhinitis $(B$. bronchiseptica and $P$. multocida bacterin-toxoid) approximately six and two weeks prior to farrowing.

\subsection{Nasal specimens and transport}

Swabs of cotton fibers and aluminum shaft were introduced in previously cleaned nostrils of each piglet. And than they were transferred to Amies medium and transported at room temperature (as determined in the transport media experiment of this study) to the laboratory.

\subsection{Culture procedures}

All swabs were processed in laboratory before $24 \mathrm{~h}$. They 
were streaked on MacConkey agar surface, modified G20G and ceftiofur medium (developed in this study) and all three media were incubated at $37^{\circ} \mathrm{C}$ for 48 hours. And the identification of $B$. bronchiseptica was based on colony morphology and biochemical characteristics, as previously proposed (19).

\section{Comparison of culture and PCR for detection of Bordetella bronchiseptica}

The same 50 nasal specimens used in the experiment of primary isolation media were submitted to PCR, after preservation into $1.5 \mathrm{~mL}$ microtubes, containing near $1 \mathrm{~mL}$ of own transport medium of swab tubes and stored at $-20^{\circ} \mathrm{C}$. Total DNA was extracted from nasal swabs using the guanidine thiocyanate method, as described elsewhere Boom et al. (2) and PCR was based in the method proposed by Hozbor et al. (14) with the primers Fla2- 5'AGGCTCCCAAGAGAGAAAGGCTT- 3', Fla4- 5'TGGCGCCTGCCCTATC-3'. Amplification was performed in $25 \mu \mathrm{l}$ containing $5 \mu \mathrm{l}$ of DNA template, $1.5 \mathrm{mM} \mathrm{MgCl}_{2}$, $200 \mu \mathrm{M}$ each dNTP, $20 \mathrm{pmol}$ of each primer, $1.0 \mathrm{U}$ of Taq DNA polymerase (LGC Biotecnologia, São Paulo), 1X PCR buffer and ultra pure water. Amplified products were separated by electrophoresis in 1.5\% agarose gel stained with ethidium bromide. The 100-bp DNA ladder (LGC Biotecnologia, São Paulo) was used as a molecular size marker.

\section{Statistical analysis}

The percentage of recovered B. bronchiseptica in the transport medium determination was compared by Fisher's Test and the number of $\mathrm{CFU} / \mathrm{mL}$ was analyzed by GLM procedure, following its logarithmic conversion. Mean values were compared by Tukey-Kraemer (temperature $27^{\circ} \mathrm{C}$ ) or ttest (temperature $10^{\circ} \mathrm{C}$ ).
No statistical analysis was made to determine which selective medium had the best performance or to compare culture to PCR detection. In both cases a simple comparison between the reached percentages by each medium (selective medium determination) or each method (culture or PCR detection) was processed.

\section{RESULTS}

\section{Transport medium}

The qualitative growth of $B$. bronchiseptica in the three transport formulations at $10^{\circ} \mathrm{C}$ and $27^{\circ} \mathrm{C}$ incubation is presented in Table 1. The recovery capability of Amies and PBS was higher than TSB during the first $72 \mathrm{~h}$ when swabs were incubated at $10^{\circ} \mathrm{C} \quad(\mathrm{P}<0.05)$. Due to low $B$. bronchiseptica recovery with TSB formulation at $10^{\circ} \mathrm{C}$ in the first 72 hours, the quantitative comparison of recovery capabilities of $B$. bronchiseptica was performed only between Amies and $\mathrm{PBS}+\mathrm{S}$ formulation. The number of recovered $B$. bronchiseptica cells at 24 and 72 hours was similar between Amies and PBS + S. However, at 120 hours incubation, Amies medium obtained a significantly higher bacterial count as compared to PBS $+\mathrm{S}$ (Table 2). Up to 72 hours, $\mathrm{PBS}+\mathrm{S}$ and TSB presented no significant differences, but were superior to Amies. And at 120 hours, all the formulations differed significantly, and the highest recovery rate was obtained with TSB, followed by PBS + S and Amies (Table 2).

\section{Selective medium}

On ceftiofur medium B. bronchiseptica formed after $48 \mathrm{~h}$ of incubation small (near $1.2 \mathrm{~mm}$ diameter), convex, smooth, green to blue with darker centre, transparent colonies with a blue reaction in the medium around them. This colony morphology was quite similar to the morphology presented G20G medium, which presented superior diameter (1.5- 

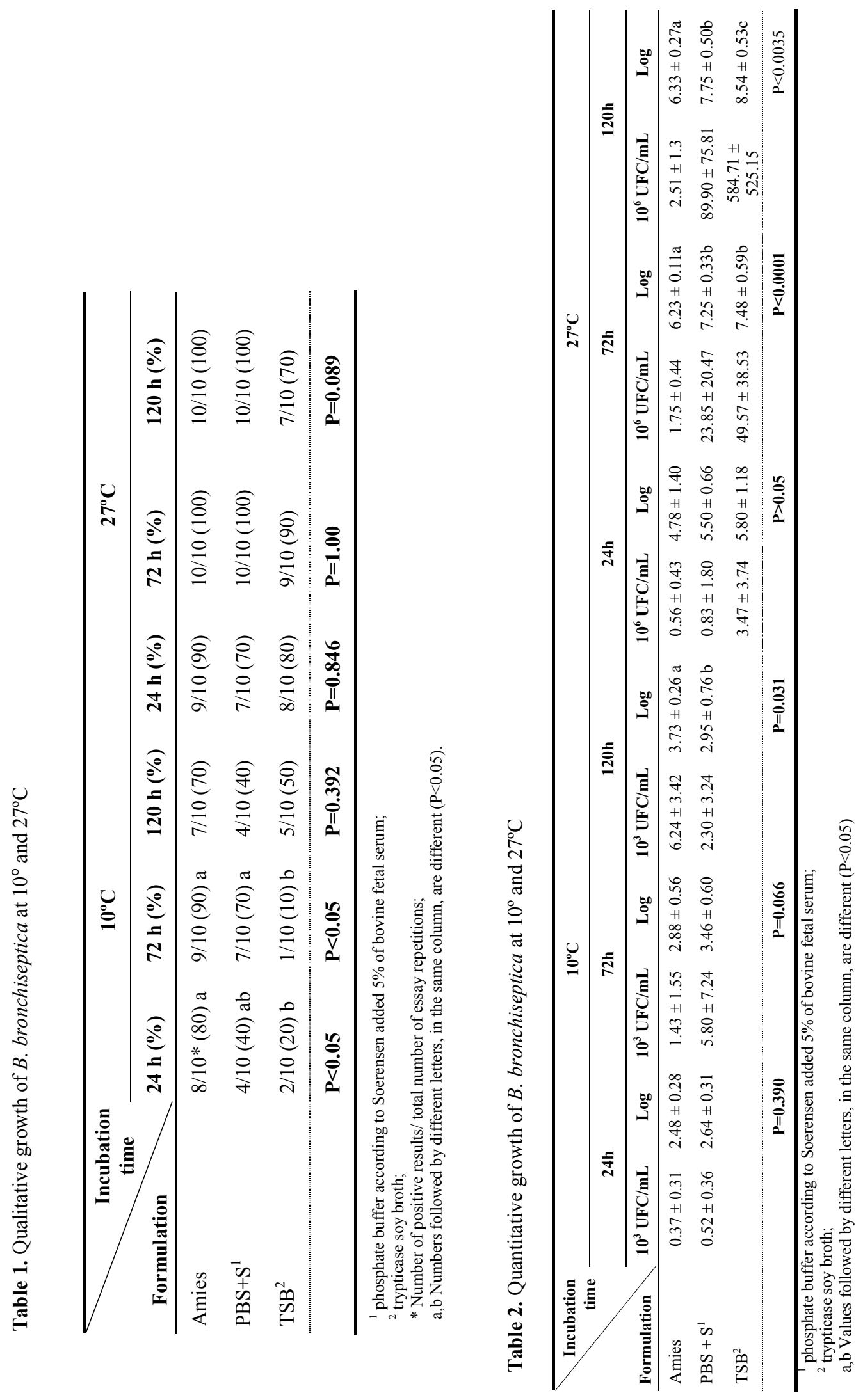

$\underset{⿱}{*}$ 
$2.0 \mathrm{~mm}$ ) and inferior transparence. And the colonies on MacConkey agar were small (inferior to $1.0 \mathrm{~mm}$ ), convex, smooth, with pink hue and amber discoloration of the underlying medium.

Nine (18\%) swine were positive for B. bronchiseptica isolation. The recovery rate of $B$. bronchiseptica was similar on MacConkey agar and modified G20G agar (14\%, 7/50 samples), however, on this last medium the contaminant flora was present in higher number than MacConkey agar. The ceftiofur medium showed the worst performance, with $8 \%(4 / 50)$ recovery rate. And considering the three selective media together, it increased the isolation capability of each alone.

\section{Comparison of culture and PCR results}

Among sampled piglets, 26\% (13/50) were positive by PCR (Figure 1.), 18\% (9/50) by culture and the two techniques had 14\% (7/50) of concordance in positive results. Analyzing each tested isolation medium alone, PCR agreed positively with isolation on MacConkey agar, modified G20G and ceftiofur medium, respectively, in $12 \%, 10 \%$ and $8 \%$ assays. PCR technique failed to detect B. bronchiseptica when compared to positive isolation in MacConkey, modified G20G and ceftiofur medium, respectively, in 2\%, 4\% and $0 \%$ assays. MacConkey agar, modified G20G and ceftiofur medium failed to isolate B. bronchiseptica when PCR was positive, respectively, in $14 \%, 16 \%$ and $18 \%$ assays.

\section{DISCUSSION}

B. bronchiseptica survived best in a transport system at $27^{\circ} \mathrm{C}$ and this could be explained by the nearness of this temperature to the optimal thermal condition of $B$. bronchiseptica as compared to the temperature $10^{\circ} \mathrm{C}$. At

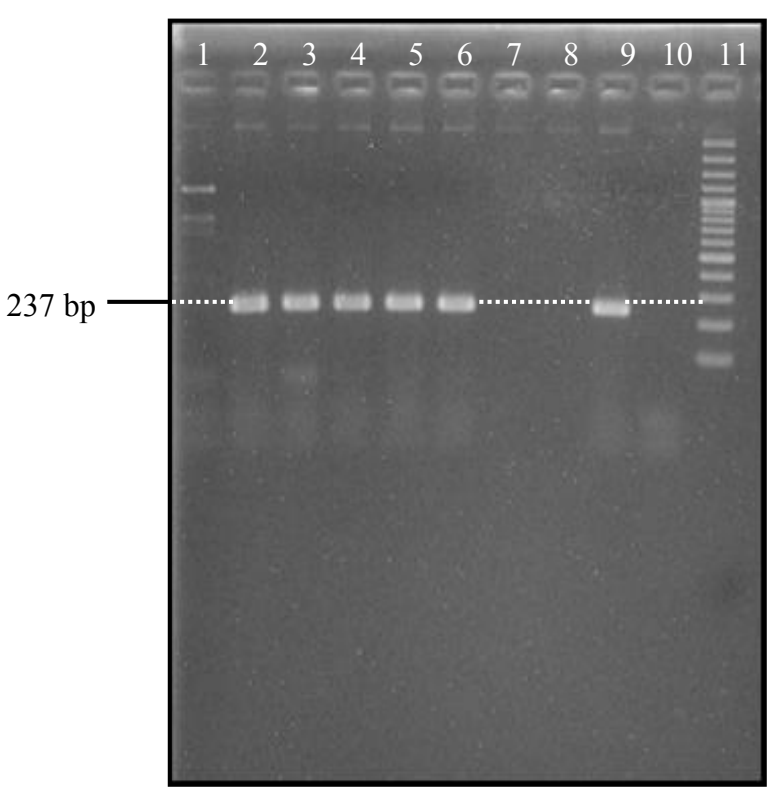

Figure 1. Amplification of a 237 bp segment of $B$. bronchiseptica DNA. Lane 2 to 6 show positive samples, lane 7 and 8 depict negative samples, lane 9 and 10 indicate the negative and positive controls and lane 11 contains molecular weight marker.

room temperature, the organism starts its multiplication and the medium then harbors greater numbers of bacteria, easing survival during transportation (13). However, some authors demonstrated that room temperature should not be recommended, since overgrowth occurs and Bordetella does not multiply significantly (11). This is what possibly has happened in this study, since TSB, that represents the most nutritional medium among the three tested formulations, recovered $B$. bronchiseptica in fewer opportunities than Amies and $\mathrm{PBS}+\mathrm{S}$, probably due to competition with the mixed bacteria.

At $27^{\circ} \mathrm{C}$, Amies medium showed the worst quantitative performance after 72 hours and this was already expected, 
since TBS has a rich nutritional composition and $\mathrm{PBS}+\mathrm{S}$ was supplemented with bovine fetal serum. The number of $B$. bronchiseptica cells on Amies medium and in $\mathrm{PBS}+\mathrm{S}$ formulation at $10^{\circ} \mathrm{C}$ remained almost stable, with a slight increase up to 120 hours. The low temperature of incubation could possibly delay microorganism growth by a decrease of enzymatic activity (1).

When B. bronchiseptica was recovered, independently of thermal condition, the number of bacteria was never inferior to initial inoculum, attesting the three tested formulations as good media to maintain the viability of this pathogen during it transport to laboratory. However, at $10^{\circ} \mathrm{C}$ incubation Amies medium or $\mathrm{PBS}+\mathrm{S}$ formulation recovered in average $99 \%$ less $B$. bronchiseptica cells than at $27^{\circ} \mathrm{C}$ during the three recovery periods tested. Morrill et al. (22) also related that specimens transported at refrigerated temperature $\left(4^{\circ} \mathrm{C}\right)$ showed suppressed overgrowth, in the case of their study the B. pertussis colony numbers decreased by $75 \%$.

The ceftiofur medium showed the worst result when compared to MacConkey agar and modified G20G regarding capacity of bacterial isolation. In contrast to our results, Lariviere et al. (16) found better performance of a selective medium for $B$. bronchiseptica using another cephalosporin (cephalexin) as the selective agent, comparing with MacConkey agar and G20G.

PCR obtained superior capability of B. bronchiseptica detection to culture in all three selective media. This could be explained by the fact that PCR does not distinguish between dead and viable bacteria (13).

The disagreement between culture and positive PCR could be explained by the higher sensitivity of the molecular technique. The sensitivity of culture could be affected by factors such as low number of $B$. bronchiseptica cells in nasal cavity (assymptomatic piglets) (26), presence of damaged or dead $B$. bronchiseptica cells before or during processing and animals previously submitted to antimicrobial therapy.

The disagreement of PCR with positive culture can be traced to several variables. Too few bacteria in nasal swabs could affect PCR sensitivity, as found in the usual protocol, which needs at least 10 organisms of $B$. bronchiseptica for detection (14). Components of swab (shafts and head fibers) could also inhibit PCR (31). In our work we collected specimens using aluminum shaft and cotton fiber head swabs, but apparently the composition had no negative influence in $B$. bronchiseptica detection, since PCR was more sensitive than culture. This finding needs to be validated, as we used just one type of swab. Other authors also did not find any inhibitory effect with swabs containing aluminum shafts (3). Some components of the transport medium, such as agar, could still affect PCR sensitivity (10). We used Amies medium and it contains agar, however it seemed not to affect the PCR, since samples containing pure culture of $B$. bronchiseptica immersed in Amies medium were previously successfully detected by PCR. DNA damage during storage could also negatively affect PCR, since the period of time between specimen collection and processing in our experiment was almost two months. Other hypothesis to explain the failure of PCR to detect B. bronchiseptica could be related to the presence of infection with a strain with an altered or mutated sequence in the region defined by the primers (20). Dragsted et al. (6) stated that the main factor that determines the quality of a PCR method is the design of primers, which should target a highly specific and preserved sequence in bacterial genome. The PCR protocol used in our study is highly specific, since the target DNA region chosen for primers design is the upstream region of the fla gene, a highly specific and preserved sequence in the $B$. bronchiseptica genome (14). The authors confirmed the 
sensitivity and specificity of this PCR protocol testing $30 \mathrm{~B}$. bronchiseptica, $30 \mathrm{~B}$. pertussis, $30 \mathrm{~B}$. parapertussis and different isolates of bacterial and fungal genera often detected in the human respiratory tract (Aspergillus sp., Candida sp., Chlamydia sp., Haemophilus sp., Legionella sp., Mycoplasma sp., Staphylococcus sp. and Streptococcus sp.).

\section{CONCLUSIONS}

Amies and $\mathrm{PBS}+\mathrm{S}$ were the most efficient transport media at $27^{\circ} \mathrm{C}$ of incubation, however Amies medium was pointed as the preferential transport medium due to the ease of preparation.

MacConkey agar and modified G20G could be employed successfully for $B$. bronchiseptica primary isolation. Nevertheless, considering the number of recovered colonies in each medium, the ease of production and cost, MacConkey was considered the choice medium.

Culture was less sensitive than PCR. Even using the best transport temperature and medium and using the most sensitive selective medium as defined in our study.

And while the combined use of molecular and bacteriological detection has markedly increased the detection capability as compared to the use of a single method, it was shown that only part of clinically diagnosed cases could be confirmed, pointing for the possible underestimated impact of $B$. bronchiseptica infection in swine herds.

\section{RESUMO}

Desempenho de meios de transporte e seletivo na recuperação de Bordetella bronchiseptica de suínos e sua comparação à deteç̧ão pela reação em cadeia pela polimerase
Três ensaios comparativos foram feitos com o objetivo de aperfeiçoar a sensibilidade do diagnóstico da infecção pela Bordetella bronchiseptica a partir de suabes nasais de leitões. O experimento inicial comparou a recuperação de $B$. bronchiseptica a partir de suabes, simultaneamente inoculados com B. bronchiseptica e algumas bactérias interferentes, imersos em três formulações para transporte (meio Amies com carvão, caldo tripticaseína de soja e tampão de fosfatos segundo Soerensen suplementado com $5 \%$ de soro fetal bovino) e submetidos a diferentes temperaturas $\left(10^{\circ} \mathrm{C}\right.$ e $\left.27^{\circ} \mathrm{C}\right)$ e períodos de incubação $(24,72$ e 120 horas). O experimento subseqüente comparou três meios seletivos (ágar MacConkey, meio seletivo G20G modificado e o meio de ceftiofur) em relação às suas capacidades de recuperação a partir de amostras clínicas. $\mathrm{O}$ último experimento comparou a reação em cadeia pela polimerase aos três meios seletivos. No primeiro experimento, a recuperação de $B$. bronchiseptica nos sistemas de transporte foi melhor a $27^{\circ} \mathrm{C}$ e as três formulações tiveram boas performances nesta temperatura, mas o conjunto das análises qualitativa e quantitativa apontou para o uso preferencial do meio Amies para o transporte de suabes nasais. O segundo experimento indicou que o ágar MacConkey e o G20G modificado mostraram resultados similares e foram superiores ao meio de ceftiofur. No experimento final, a técnica de reação em cadeia pela polimerase apresentou uma capacidade de detecção da B. bronchiseptica superior a do cultivo.

Palavras-chave: Bordetella bronchiseptica, suínos, meios de transporte, meios seletivos, PCR

\section{REFERENCES}

1. Black, J.G. (1999). Microbiology: principles and explorations. John Wiley \& Sons, New York, NY. 
2. Boom, R.; Sol, C.J.A.; Salimans, M.M.M.; Jansen, C.L.; WertheinVanDillen, P.M.E.; Van der Noordaaa, J. (1999). Rapid and simple method for purification of nucleic acids. J. Clin. Microbiol., 28 (3), 495-503.

3. Cloud, J.L.; Hymas, W.; Carroll, K.C. (2002). Impact of nasopharingeal swab types on detection of Bordetella pertussis by PCR and culture. $J$. Clin. Microbiol., 40 (10), 3838-3840.

4. De Jong, M.F. (1999). Progressive and nonprogressive atrophic rhinitis. In: Straw, B.E.; D’Allaire, S.; Mengeling, W.L.; Taylor, D.J. Diseases of Swine, 8th.ed., Iowa State University Press, Ames, Iowa, p. 355-385.

5. Douglas, E.; Coote, J.G.; Parton, R.; McPheat, W. (1993). Identification of Bordetella pertussis in nasopharyngeal swabs by PCR amplification of a region of the adenylate cyclase gene. J. Med. Microbiol.,38, 140144.

6. Dragsted, D.M.; Dohn, B.; Madsen, J.; Jensen, J. (2004). Comparison of culture and PCR for detection of Bordetella pertussis and Bordetella parapertussis under routine laboratory conditions. J. Med. Microbiol., 53, 749-754.

7. Eisenstein, B.I. (1990). New opportunistic infections - more opportunities. N. E. J. Med., v.323, p.1625-1632.

8. Farrell, D.J.; Daggard, G.; Mukkur, T.K. (1999). Nested duplex PCR to detect Bordetella pertussis and Bordetella parapertussis and its application in diagnosis of pertussis in nonmetropolitan Southeast Queensland, Australia. J. Clin. Microbiol., 37, 606-610.

9. Furuya, D.; Yagihashi, A.; Endoh, T.; Uehara, N.; Fujii, N.; Chiba, S.; Watanabe, N. (1999). Simultaneous amplification of Bordetella repeated insertion sequences and toxin promoter region gene by polymerase chain reaction. Immunopharmacol. Immunotoxicol, 21, 5563.

10. Gibb, A.P.; Wong, S. (1998). Inhibition of PCR by agar from bacteriological transport media. J. Clin.Microbiol., 36 (1), 275-276.

11. Halperin, S.A.; Bortolussi, R.; Wort, A.J. (1989). Evaluation of culture, immunofluorescence, and serology for the diagnosis of pertussis. $J$. Clin. Microbiol., 27 (4), 752-757.

12. Harris, D.L.; Ross, R.F.; Switzer, W.P. (1969). Incidence of certain microorganisms in nasal cavities of swine in Iowa. Am. J. Vet. Res., 30, 1621-1624.

13. Hoppe, J.E. (1999). Bordetella. In: Murray, P.R.; Baron, E.J.; Pfaller, M.A.; Tenover, F.C.; Yolken, R.H. Manual of Clinical Microbiology. ASM Press, Washington, DC:, p.116-137.

14. Hozbor, D.; Fouque, F.; Guiso, N. (1999). Detection of Bordetella bronchiseptica by the polymerase chain reaction. Res. Microbiol., 150, 333-341.
15. Jenkins, E.M.; Anthony, V.; Vance, R.T.; Cleveland, B.S.; Gbadamosi, S.G. (1977). Prevalence of Bordetella bronchiseptica infection in swine of southeastern Alabama. Am. J. Vet. Res., 38, 2071-2074.

16. Lariviere, S.; Leblanc, L.; Mittal, K.R.; Martineau, G.P. (1993). Comparison of isolation methods for the recovery of Bordetella bronchiseptica and Pasteurella multocida from the nasal cavities of piglets. J. Clin. Microbiol., 31 (2), 364-367.

17. Liesack, W.; Stackerbrandt, E. (1992). Occurrence of novel groups of the domain Bacteria as revealed by analysis of genetic material isolated from an Australian terrestrial environment. J. Bacteriol., v.174, p.5072.

18. Longo, D.S.; Schuch, D.M.; Rossoni, E.M.M.; Hoff, J.F.; Hatano, K.; Ichikawa, T.; Figueiredo, V.L. (1991/1992). Controle de Qualidade. In: Longo, D.S.; Schuch, D.M.; Rossoni, E.M.M.; Hoff, J.F.; Hatano, K.; Ichikawa, T.; Figueiredo, V.L. Métodos de Análise Microbiológica para Alimentos, Ministério da Agricultura, do Abastecimento e da Reforma Agrária, p.6-19.

19. MacFaddin, J.F. (2000). Biochemical tests for identification of medical bacteria. 3rd ed. Lippincott Williams \& Wilkins, New York, NY, p. 912.

20. Maede, B.D.; Bollen, A. (1994). Recommendations for use of the polymerase chain reaction in the diagnosis of Bordetella pertussis infections. J. Med. Microbiol., 41, 51-55.

21. Miles, A.A.; Misra, S.S. (1938). Estimation of the bactericidal power of the blood. J. Hyg., 38, 732.

22. Morrill, W.E.; Barbaree, J.M.; Fields, B.S.; Sanden, G.N.; Martin, W.T. (1988). Effects of transport temperature and medium on recovery of Bordetella pertussis from nasopharyngeal swabs. J. Clin. Microbiol., 26 (9), 1814-1817.

23. Müller, F.M.C., Hoppe, J.E.; Wirsing von König, C.H. (1997). Laboratory diagnosis of pertussis: state of the art in 1997. J. Clin. Microbiol., 35 (10), 2435-2443.

24. Prescott, J.F. (2000). Beta-lactam antibiotics: cephalosporins and cephamycins. In: Prescott, J.F.; Baggot, J.D.; Walker, R.D. (Eds.). Antimicrobial Therapy in Veterinary Medicine. Iowa State University Press, Iowa, Ames, p.134-159.

25. Register, K.B.; Ackermann, M.R.; Dyer, D.W. (1995). Nonradioactive colony lift-hibridization assay for detection of Bordetella bronchiseptica infection in swine. J. Clin. Microbiol., 33 (10), 26752678.

26. Register, K.B. (2000). Bordetella bronchiseptica - An underestimated threat? Pig Progress., 16, 10-11.

27. Salmon, S.A.; Watts, J.L.; Case, C.A.; Hoffman, L.J.; Wegener, H.C.; Yancey Jr., R.J. (1995). Comparison of mic's of ceftiofur and other 
antimicrobial agents against bacterial pathogens of swine from the United States, Canada and Denmark. J. Clin. Microbiol., 33 (9), 24352444.

28. Sloan, L.M.; Hopkins, M.K.; Mitchell, P.S.; Vetter, E.A.; Rosenblatt, J.E.; Harmsen, W.S.; Cockerill, F.R.; Patel, R. (2002). Multiplex LightCycler PCR assay for detection and differentiation of Bordetella pertussis and Bordetella parapertussis in nasopharyngeal specimens. $J$. Clin. Microbiol.,40, 96-100.

29. Smith, I.M.; Baskerville, A.J. (1979). A selective medium facilitating the isolation and recognition of Bordetella bronchiseptica in pigs. Res. Vet. Sci., 27, 187-192.

30. Van der Zee, A.; Agterberg, C.; Peeters, M.; Schellekens, J.; Mooi, F.R.
(1993). Polymerase chain reaction assay for pertussis: simultaneous detection and discrimination of Bordetella pertussis and Bordetella parapertussis. J. Clin. Microbiol., 31, 2134-2140.

31. Wadowsky, R.M.; Laus, S.; Libert, T.; States, S.J.; Ehrlich, G.D. (1994). Inhibition of PCR-based assay for Bordetella pertussis by using calcium alginate fiber and aluminum shaft components of a nasopharyngeal swab. J. Clin. Microbiol., 32 (4), 1054-1057.

32. Weiss, A.A. (1992). The genus Bordetella. In: A. BALOWS, H.G. The prokariotes. A handboook on the biology of bacteria: ecophysiology, isolation, identification, applications. 2nd ed. Springer-Verlag, Berlin, Germany, v.3, p. 2530-2543. 